\title{
Assessment of water resource consumption in building construction in India
}

\author{
S. Bardhan \\ Dept. of Architecture, Jadavpur University, India
}

\begin{abstract}
Building construction is a highly resource intensive process, concerning use of materials, land, energy and water. Since buildings are required to fulfil our primary need for shelter, consumption of these resources is simply unavoidable. However, with shrinking stock of natural resources and degrading eco-system services, the consumption process has to be wise, judicious and non-wasteful. Search for alternative and recycled materials, multiple floor spaces and use of renewable energy are some of the human responses against the perceived threat of materials, land and energy constraints respectively. Water resource management in building construction and operation, however, has still a long way to go, especially because the amount of water used per unit area of construction largely remains undocumented. There has been some pioneering research on embodied water measurement of several non-residential buildings in Australia. In this backdrop, the present paper seeks to understand and assess the quantity of fresh water used in contemporary urban multi-storeyed residential buildings and reports a study conducted for a real-life project in Calcutta (now, Kolkata), India. Since the use of construction water directly varies with the type of construction, a steel and glass building will have its embodied water-footprint mainly on account of that of its materials while on-site water use plays a major role in case of a cast-in-situ reinforced cement concrete and brick building. Thus, water efficiency at the production stage is required in the first case while the second category demands concerns and actions at the consumption stage. This paper examines some of the issues related to the subject like water demand at material production as well as construction stage and the resultant embodied water of typical urban constructions in India, which was found to be in the range of about 27 Kilolitres/Sq $\mathrm{m}$ of total built-up area.
\end{abstract}

Keywords: construction water, ground water, site water management. 


\section{Introduction}

Fresh Water is a very precious natural resource and it is widely reported that the world reserve of fresh water is fast depleting. Life on earth is not possible without water. Climate change concerns across the globe has predicted severe water scarcity due to degrading eco-system services and World Business Council for Sustainable development (WBCSD) in its Vision 2050 statement has estimated an additional load of more than 500 million people under water-stress conditions in the BRIC (Brazil-Russia-India-China) countries by 2030 [1]. In India, with the National Action Plan for Climate Change (NAPCC) and its constituent National Water Mission, a target of $20 \%$ increase in water-use efficiency has been set to counter the challenge [2]. The National Water Policy of Government of India recognizes the need of planning the economic activities like agriculture, industries and urban development in conformity with availability of this life-sustaining resource and has recommended water-zoning [3]. From the point of view of urban development, building industry is known to be a major consumer of water resource, which in many cases, is the ground water extracted through bore-wells. There also had been reports of major subsidence threats due to over-exploitation of this important reserve in a particular segment of the city of Calcutta (now, Kolkata), India.

In a building's entire life-cycle, water and energy are considered to be the two major pillars that support human activities in it. While there are many studies on embodied energy and recurring energy consumption in buildings, such database appears scanty in the field of water. Similarly, embodied energy of building constituent materials is also available along-with their embodied $\mathrm{CO}_{2}$ emission factor, which is again not the case when water resource is concerned. Even industry related documents, in most cases, barely touches upon water use in their raw materials' inventory. Thus, there seems to be a big void when similar baseline research data availability with respect to water is looked for. Out of one of the few studies, United Nations Environment Program [4] has indicated that over an entire life-cycle, the building industry consumes a global average of $30 \%$ of fresh water and generates $30 \%$ of world's effluents. In India, the manual on water supply and treatment [5] has indicated water consumed per unit production of steel and it is, thus, one of the few building materials having a recorded water foot-print. Other major building materials like bricks, cement, aluminium, glass etc. use considerable quantity of water in their manufacturing process through extraction and processing, though data on their water-foot print is not readily available. In this backdrop, the present paper seeks answers to the following research questions:

- Is it possible to know the capital water content or water foot-print of a building in India? This is precisely its embodied water.

- To know the above, it will also be important to know the water foot-print or embodied water of its constituent materials, at least the common ones. Is there any such data or reported research finding for Indian products in this area? 
- It will also be important to understand the amount of water used during the actual construction process, both direct and indirect. How can this construction water be estimated for Indian buildings?

The above key issues have been deliberated in the course of the paper to the extent possible on the basis of available data, documentation and an actual case study.

\section{Research so far}

Internationally, one particular research team has been known to have done extensive research in this field. Researchers in Australia [6, 7] and their studies suggest that embodied water is many times greater than the volume of water used during a building's life. The team working at Deakin University, Victoria, looked at 17 non-residential case studies in Australia and found that embodied water could be as much as 20 kilolitres per $\mathrm{m}^{2}$ of gross floor area, but that water required during the construction process was minimal. The buildings studied include examples from the health, education and commercial sectors; and the team looked at the embodied water of the structure, substructure, finishes, roof and services. The UK concrete industry [8] has agreed on a 'Concrete Industry Sustainable Construction Strategy' and has reported that "though no studies have been done on homes in the UK, a 2004 study in Australia estimated that a typical Australian house represents about 15 years worth of operational water i.e. water used for cooking, cleaning, washing, drinking, toilet flushing and gardening. This study estimated that a kilo of concrete has about two litres of embedded water, a kilo of timber about 20 litres, a kilogram of steel about 40 litres, a kilo of aluminium about 88 litres, and that a kilogram of plastic has about 185 litres of embedded water." This reporting shows that there has been sufficient work in finding out the embodied water in building materials and structures in Australia, though no such research has been reported from India. In contrary, operational water use has been under recent focus by one of the leading national organizations. Centre for Science and Environment, New Delhi, India [9] has taken up a study for developing water efficiency labeling and standards in Indian conditions. This study is aimed at rating fixtures like dual flush toilets, low water using/ sensor based/waterless urinals, sensor faucets/faucets with flow restrictors, water efficient showers etc. according to their efficiency, much like what has already been done for electrical appliances. However, studies on embodied water content of buildings being relatively complex involving multistage activities - raw material extraction, manufacture and construction - have not yet been conclusively reported by either industry or academic groups. It may be presumed that even if research is on-going in this area, results from more than one source will only substantiate the findings and will help to draw closer to accuracy by collating the output data. 


\section{Significance in national context}

Reducing water consumption and improving water efficiency in buildings is a major step towards sustainable water management [8]. Unless the embodied water content of a building is known or measured, water management is not possible. Rampant misuse of water will continue and the objectives of National Water Policy of better water management practices and improvement in operational technology will remain unfulfilled. Further, this is integrally linked with sustainable building concepts and sustainable development issues. Life Cycle Analysis (LCA) of buildings and its corresponding eco-profile is considered to be a rational method of quantifying the 'environmental impact' or 'greenness' of a building [10]. However, this is dependent on real-life resource consumption amounts and other relevant data that are at present not available or are difficult to ascertain because of lack of base-line research in this area. Hence, LCA of buildings are currently carried out with assumed figures and therefore, seldom give the true picture. The present study intends to contribute in filling up these research gaps. With water shortages likely to grow in significance around the world due to climate change and Indian construction industry growing at an astounding rate of $10 \%$ per annum over the last ten years [11], this is an issue that needs immediate attention. The indigenous green building rating system titled Green rating for Integrated Habitat Assessment (GRIHA) has stipulated points for buildings which are resource efficient. The results of this study can be integrated into the ratings to determine a measurable and objective way of assessing their sustainability. This will give greater credence to the rating system and its scientific basis. It is expected that the architect community, real estate industry and general public will be more conscious and judicious in future wateruse. Studies on multiple live case studies can create baseline data to help in framing appropriate policies for achieving water use reduction. This will support the goals of sustainable development, National Water Policy and National Water Mission under NAPCC.

\section{Embodied water assessment in buildings}

A group of multi-storied residential apartment building of steel and RC construction located in the southern part of the city of Calcutta in the Eastern Indian state of West Bengal was selected for studying its embodied water content. This project is a prototype of the developmental activities taking place in the housing sector in the entire country. It is meant for people belonging to high income group and is also designed for luxurious life-style. Thus, the choice of materials and the quality of construction are both superior. Understandably, for the type of construction mentioned above, steel and cement form the two most volumetrically significant as well as water-intensive materials, the latter requiring water at both production and construction stage. The total built-up area of the apartments together exceeds three million square feet and was constructed between the years 2002 and 2008. The site had a total of six bore wells to supply water for construction of the said building group. 


\subsection{Methodology}

The methodology presented here involves two stages- one that assesses the embodied water of the materials used in the building and the second assesses the amount of water used during the construction process. The project office of the building was approached to access the materials' purchase records and the assessment was carried out on the basis of the figures provided by them. However, it is important to note that a large amount of construction was made from Ready Mix Concrete, whose embodied water content needs specific study and has not been covered here. The major building materials having the highest stake in the constructed volume such as bricks, cement and steel were considered in the first stage of assessment as presented in table 1. The second stage had two optional methods- the first one involving theoretical calculation of the water requirement for concrete mixes and curing of brick masonry as well as concrete castings, while the other depends on data collection on water consumption directly from site sources to have an idea on the various indirect and otherwise unrecorded heads for which water is used during construction like watering for sub-grade stabilization, dust control, water line testing and cleaning, use by onsite resident construction labours, so on and so forth. Research on concrete mixes in Indian conditions have estimated a savings of 7,500,000 tonnes of cement as well as $3,750,000$ Kilolitre of potable water by the use of water-reducers for concrete mixes with 50 million tonnes of cement, indicating 2 Kilolitres of water requirement per ton of cement used in concrete mixes [12]. To account for the indirect component of water usage, this paper follows the second line of investigation and presents the water consumption assessment during construction stage from data released by the project office on the electrical energy expended on account of water pump operation at site. These figures were converted to equivalent water quantity on the basis of known yield of the bore wells as presented in table 2. The outcome of both the stages is expressed in Kilolitres per $\mathrm{Sq} \mathrm{m}(\mathrm{Kl} / \mathrm{Sq} \mathrm{m})$ i.e. water used per unit floor area of the constructed building. The total embodied water of the building will be given by the sum of these two amounts.

Table 1: Assessment of embodied water in the materials of the case study.

\begin{tabular}{|l|l|l|l|l|l|l|}
\hline Sl. & Materials & $\begin{array}{l}\text { Quantity } \\
\text { used }\end{array}$ & Unit & $\begin{array}{l}\text { EW } \\
\text { Coefficient }\end{array}$ & $\begin{array}{l}\text { Total } \\
\text { Embodied } \\
\text { water in } \\
\text { material }\end{array}$ & $\begin{array}{l}\text { Embodied } \\
\text { water per } \\
\text { unit floor } \\
\text { area }\end{array}$ \\
\hline & & & & $\mathrm{K} 1 /$ unit & $\mathrm{Kl}$ & $\mathrm{Kl} / \mathrm{Sq} \mathrm{m}$ \\
\hline 1 & Cement & 154,858 & Ton & 1 & 154,858 & 0.5 \\
\hline 2 & Bricks & 42849.37 & Cum & 0.71 & 30423 & 0.1 \\
\hline 3 & Steel & 38906 & Ton & $200-250$ & 7781200 & 25 \\
\hline 4 & Aluminium & 15143 & $\mathrm{Kg}$ & 0.088 & 1332.584 & 0.004 \\
\hline & \multicolumn{7}{|l|}{ Total embodied water of the major materials } & 25.604 \\
\hline
\end{tabular}


Table 2: $\quad$ Water consumption for 68 months during construction.

\begin{tabular}{|c|c|c|c|c|}
\hline $\mathrm{A}$ & $\mathrm{B}$ & $\mathrm{C}=\mathrm{A} / \mathrm{B}$ & $\mathrm{D}$ & $\mathrm{DxC} / 1000$ \\
\hline $\begin{array}{l}\text { Energy } \\
\text { consumed in } \\
21 \text { months } \\
\end{array}$ & $\begin{array}{l}\text { Capacity of } \\
\text { Water Pumps }\end{array}$ & $\begin{array}{l}\text { Duration of } \\
\text { operation }\end{array}$ & $\begin{array}{l}\text { Yield of } \\
\text { bore well }\end{array}$ & $\begin{array}{l}\text { Total water } \\
\text { consumed }\end{array}$ \\
\hline KWh & $\mathrm{kW}$ & Hours & $\begin{array}{l}\text { Litres per } \\
\text { Hour (lph) }\end{array}$ & $\mathrm{Kl}$ \\
\hline \multirow[t]{3}{*}{972319.44} & $\begin{array}{lr}5.595 & (7.5 \\
\text { H.P) \&7.46 } & \\
(10.0 & \text { H.P. })\end{array}$ & 24826.23 & $\begin{array}{ll}18,000 \quad \& \\
24,000\end{array}$ & \\
\hline & $\begin{array}{l}\text { Average: } \\
6.5275 \\
\end{array}$ & & & \\
\hline & $\begin{array}{l}\text { For } 6 \text { pumps: } \\
39.165 \mathrm{~kW}\end{array}$ & & 21000 & 521350.83 \\
\hline
\end{tabular}

\subsection{Embodied water attributed by materials}

As mentioned earlier, only the major stake holding materials have been considered in this study, especially as the embodied water in these materials in Indian scenario were found to be somewhat available. However, these figures either came in from more than a decade old documents or had to be calculated from mentions in studies and researches with different thrust areas. These are explained in the following text:

Cement: In an industrial documentation study of Central Pollution Control Board [13], different values were obtained on water consumption in cement industry. It was found to be varying between $0.5 \mathrm{Kl} /$ ton to $1 \mathrm{Kl} /$ ton. For the purpose of this study, $1 \mathrm{Kl} /$ ton has been considered as embodied water foot-print of cement.

Steel: Manual on water supply and treatment [5] specifies water embodied in steel as 200-250 Kl/ton of steel manufacture. Although this is excessively high compared to that obtained in international studies, which is in the range of 40 Litres/ $\mathrm{Kg}$ or $40 \mathrm{Kl} /$ ton [8], this is the only authentic figure obtained in Indian context and, therefore, considered in this paper.

Brick: Brick manufacturing sector in India is largely informal and without much documentation on its water consumption per unit of production. A technical note of Brick Industries' Association [14] mentions water requirement as $20-30 \%$ of clay amount, which works out to be about 300 Litres/Cum of brick manufacture. Local practice, however, would certainly involve much more water, not only because of water abundance, but also owing to lesser awareness of water issues. Hence, this paper draws parallel between the consistency in concrete mix with that of brick and builds on the water-cement ratio of M20 concrete to arrive at the possible water quantity in brick manufacture [15]. This works out to be $714 \mathrm{Litres} / \mathrm{Cum}$, more than double the previous figure. The total brick volume used in the building fabric was obtained from the number of bricks purchased by the Project. 
Additionally, in the interest of research, a fourth material - Aluminium has also been included as its embodied water was available from International reports [8], though its contribution, as expected, is insignificant.

\subsection{Water consumption during actual construction}

The data of electrical expenses on account of on-site water pumping during construction period was available for some 68 months. This monetary value was converted into energy consumed in Kilo-Watt-Hour ( $\mathrm{kWh}$ ) by dividing it with the unit energy rate, considered here to be 3.91 INR as per available contemporary data and the energy consumed by the water pumps was calculated. Total energy equivalent for water resource use was found to be $972319.44 \mathrm{kWh}$ for these 68 months. As mentioned earlier, the construction water was supplied by the six on-site bore wells. The capacities of on-site water-pumps, as obtained from site sources, were 7.5 H.P and 10.0 H.P. The quantity of water consumed during the process of construction was, thus, calculated based on the known discharge capacity or the yield of the pumps. This Water foot-print calculation for rest of the construction period i.e. 81 months was extrapolated from the results obtained. The running of water-pumps for approximately $12 \mathrm{hrs}$ a day also validated the total number of pump operation hours obtained from this assessment.

Thus the water consumption for 68 months comes to around $521350.83 \mathrm{Kl}$ for the building construction. Assuming uniform rate of pump operation throughout the construction period, the total Water Consumption $\left(\mathrm{W}_{\mathrm{C}}\right)$ for the 81 months of construction works out to be $621020.84 \mathrm{Kl}$. The total built-up area of the building group being $310173.22 \mathrm{Sq} \mathrm{m}$, embodied water $\left(\mathrm{W}_{\mathrm{A}}\right)$ per unit area constructed is $\mathrm{W}_{\mathrm{A}}=\mathrm{W}_{\mathrm{C}} /$ Built-up area $=2 \mathrm{Kl} / \mathrm{Sq} \mathrm{m}$. A previous study had estimated the construction water use of a three storied $1150 \mathrm{Sq} \mathrm{m}$ building of $\mathrm{RC}$ construction to be $1 \mathrm{Kl}$ per Sq $\mathrm{m}$ [15] in the same region and therefore, the present finding appears reasonably acceptable.

\subsection{Results and discussion}

Inferring from the above calculations, the embodied water of the major building materials together worked out to be $25.604 \mathrm{Kl} / \mathrm{Sq} \mathrm{m}$ while the water consumed during the actual construction was $2 \mathrm{Kl} / \mathrm{Sq} \mathrm{m}$. Hence, the total embodied water in a typical urban construction in Calcutta, India was found to be $27.604 \mathrm{Kl} / \mathrm{Sq} \mathrm{m}$ of built area, compared to $20 \mathrm{Kl} / \mathrm{Sq} \mathrm{m}$ of Gross Floor Area as found by the research team in Australia. The present finding for the Indian building is about $38 \%$ higher than buildings in Australia. In other words, water consumed for the construction of the entire building translates into $8562021.56 \mathrm{Kl}$ of water, equivalent to a cube of about 205 metre side and the amount of water needed by nearly 34 families with five members each for one whole year at 138 litres per capita per day (lpcd). In terms of share, the contribution of steel is the highest at about $97.6 \%$ and surpasses all other materials like cement and brick. The water consumption during the actual construction process was found to be only $8 \%$ of total embodied water of the materials together. This shows that water 
consumption at material production stage i.e. the industries have to be more conscious about usage of fresh water and look for ways to bring this down through reuse and recycling. The emerging field of water governance may focus on this area and initiate drives that will achieve this goal. In future, water may prove to be an even more crucial challenge than energy, having far-reaching implications in areas of climate change, human habitation, health and economics.

\section{Conclusion}

Since water is everybody's business and any water disaster will affect population cutting across socio-economic classes, water mapping in building industry is not only significant to understand the dynamics of water resource consumption in one of the key sectors of urbanization, but also to select and decide on the most appropriate strategy to monitor and optimize this quantity for global sustainability and water management issues. This paper presented a study that intended to assess the possible range of water amount locked in the building fabric as its embodied water. It considers a live case study in the fast growing city of Calcutta and adopts a simple methodology to conduct this assessment. The result indicates the embodied water to be about $27.6 \mathrm{Kl}$ per Sq $\mathrm{m}$ of built up area of a multi-storied apartment building of steel and $\mathrm{RC}$ construction. It has also assessed the percentage contribution of steel- the single-most water intensive material as well as that of the actual construction process in the total embodied water foot-print of the case-study. However, it is understood that one case-study with limited information on embodied water of building materials is not enough. Further research explorations into water foot-print estimation of individual materials and multiple case studies for different climatic zones of India will be required to reach substantial accuracy. In practice, thoughts and action towards water metering in industries as well as at construction sites may be imperative in immediate future to map and monitor this essential resource for over-all sustainable development.

\section{Acknowledgements}

The author is grateful to All India Council for Technical Education (AICTE) and Department of Science \& Technology, Govt. of India for their financial support in carrying out this study.

\section{References}

[1] Vision 2050: Key messages; World Business Council for Sustainable Development, www.wbesd.org/

[2] National Action Plan on Climate Change, Govt. of India, Prime Minister's Council on Climate Change. Online. http://pmindia.nic.in/Pg01-52.pdf

[3] National Water Policy-India, Govt. of India, Ministry of Water Resources. http://mowr.gov.in/writereaddata/linkimages/nwp20025617515534.pdf 
[4] United Nations Environment Program (UNEP) and Division of Technology Industry and Economics (DTIE), Eco-house Guidelines, pp. 5-6, 2006.

[5] Manual on Water Supply and Treatment, Central Public health and Environmental Engineering Organization, Government of India, pp. 13, 1999.

[6] Crawford, R. \& Treloar, G., An assessment of the energy and water embodied in commercial building construction, Australian Life Cycle Assessment Conference (4th : 2005 : Novotel, Sydney, N.S.W.), pp. 1-10, 2005.

[7] McCormack, M., Treloar, G., Palmowski L. \& Crawford R., Modelling direct and indirect water requirements of construction. Online. www.informaworld.com/smpp/content $\sim \mathrm{db}=\mathrm{all}$ ? content $=10.1080 / 09613210$ 601125383

[8] Water, Sustainable Concrete, sustainableconcrete.org.uk/concrete/ constituents_of_concrete/water.aspx

[9] Rating System for Water Efficient Fixtures: A Way to Sustainable Water Management in India, Centre for Science and Environment, New Delhi, 2010.

[10] Green buildings and climate change, www.siliconrepublic.com/greentech/item/17858-green-buildings-and-climate

[11] Construction Industry Development Council, India: India Country Report, 2005-06.

[12] Kishore, K., Save environment with green construction, Civil Engineering Portal. Online. www.engineeringcivil.com/mix-design-withSuperplasticizers.html

[13] Comprehensive Industry Document Series; Central Pollution Control Board, India. Online. http://www.ecacwb.org/node/142

[14] Technical Notes on Brick Construction; The Brick Industry Association, Online.www.gobrick.com/BIA/technotes/t9.pdf?CFID $=13100589 \&$ CFTOK $\mathrm{EN}=21091890$

[15] Bardhan, S., Carbon Foot-Print Studies and Sustainable Architectural Concepts for Coastal Eco-Tourism, unpublished Doctoral thesis, Jadavpur University, 2008. 